\title{
PERDEBATAN PARADIGMA TEORI REVOLUSI: MATAHARI ATAU BUMI SEBAGAI PUSAT TATA SURYA?
}

\author{
Thoha Firdaus ${ }^{1}$ dan Arini Rosa Sinensis ${ }^{2}$ \\ ${ }^{1}$ Program Studi Pendidikan Fisika STKIP Nurul Huda \\ 2Program Studi Pendidikan Fisika STKIP Nurul Huda \\ E-mail: thohaf@stkipnurulhuda.ac.id
}

\begin{abstract}
Abstrak
Sampai saat ini kita telah akrab tentang teori alam semesta bahwa matahari merupakan pusat dari peredaran planet-planet, ilmu itu telah kita pelajari dari tingkat dasar sampai perguruan tinggi. Kita juga telah mengetahui sejarah teori para filosof terdahulu yang terbagi oleh aliran teori geosentris dan aliran teori heliosentris, sampai saat ini teori tersebut masih menjadi perdebatan. Artikel ini membahas tentang bagaimana pemikiran para ilmuan tentang teori evolusi, dan bagaimana mereka membuktikan teori-teori mereka sehingga muncul perdebatan paradigma.
\end{abstract}

Kata kunci: Teori evolusi, peredaran planet, teori geosentris dan heliosentris.

\section{PENDAHULUAN}

Alam semesta merupakan bagian yang tidak terlepas dari dunia sains, dan astronomi merupakan cabang ilmu sains yang membahas hal tersebut. Perspektif pemikiran sains di bidang astronomi sampai saat ini masih menjadi perdebatan paradigma yang tidak kunjung usai. Buktinya saat ini banyak yang menganggap penemuan yang dilakukan NASA dianggap tidak benar.

Akhir-akhir ini ramai dibincangkan tentang hal yang sudah tidak asing dan telah lama menjadi perdebatan para ilmuan, yaitu mengenai pusat tata surya sebenarnya. Amerika Serikat, yang dikabarkan pernah berhasil mengirimkan manusia pertama di bulan, dan bahkan bermimpi mempunyai keinginan akan menjejakkan kaki untuk pertama kalinya di mars pada tahun 2030 ini ternyata di dapatkan kabar yang mengejutkan tentang hasil survei penelitian. Dalam sebuah lembaga survei yang telah dilakukan pada tahun 2012 dengan melibatkan 2.200 responden, dengan pertanyaannya "Apakah Bumi yang berputar mengelilingi Matahari atau sebaliknya, Matahari yang mengelilingi Bumi?" ternyata menghasilkan jawaban di luar dugaan. National Science Foundation mengungkapkan bahwa 1 dari 4 responden menjawab yang kedua, ini dianggap olehnya sebuah kondisi yang mengkhawatirkan soal pendidikan sains di seluruh AS (Kristanti, 2014).

Banyaknya paradigma yang berbeda oleh ilmuan tentang teori pusat alam semesta, menjadikan kita harus kembali meninjau ulang dasar keilmuan yang di dapat dari tingkat sekolah yang mengatakan matahari adalah pusat tata surya. Tinjauan ini perlu di dasarkan oleh bukti empiris yang bersesuaian dengan teori dan hasil yang relevan.

\section{HASIL DAN PEMBAHASAN}

\section{Paradigma Lama}

Teori Matahari sebagai pusat alam semesta pertama kali dicetuskan oleh Seorang ilmuwan Yunani yang bernama Aristarchus (abad ke-3 SM). Pendapat ini kemudian dibantah oleh seorang filosof Yunani lain yang bernama Aristoteles yang hidup pada tahun 384-322 SM, dan tidak ada bantahan selama 15 Abad. Lalu diperkuat oleh seorang ilmuwan yang bernama Ptolomeus yang hidup pada tahun 151-127 SM dan tidak dibantah selama 12 Abad.

Kemudian Nicolas Copernicus yang hidup pada tahun 1473-1543 M membaca buku-buku Aristarchus, akhirnya memunculkan kembali teori bahwa bumi dan planet-planet lainnya berputar 
mengelilingi matahari. Copernicus menganggap bahwa tata surya yang berpusat pada Matahari lebih logis dan indah, namun tidak memiliki bukti yang pasti. Kepler menemukan bahwa hukum yang mengatur orbit menjadi jauh lebih sederhana jika Matahari ada di pusat. Newton telah menunjukkan bahwa ini disebabkan oleh hukum gravitasi universal. Jika gravitasi bekerja, Bumi dan planet lain harus mengelilingi Matahari, karena jauh lebih besar (Cuk: 2015).

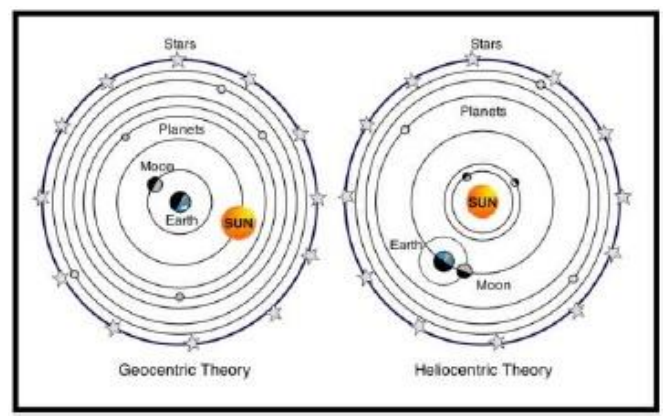

Gambar 1. Perbandingan teori geosentris dan teori heliosentris.

Pemikiran Copernicus di dukung lagi oleh Galileo yang hidup pada tahun 1564 - $1642 \mathrm{M}$, yang didukung sampai saat ini bahwa bumi dan planet-planet memutari Matahari (Gantira , 2015). Pada 1543 $\mathrm{M}$ akibat revolusi Copernicus (seorang ahli hukum dan ahli astronomi Polandia), timbul banyak ketidaksenangan terutama di kalangan rohaniawan gereja. Penyebabnya adalah pendapat Copernicus yang bertentangan dengan doktrin keagamaannya. Bahkan Martin Luther mengatakan, "Copernicus sudah gila dan teorinya dianggap melawan Injil serta tidak dapat diterima".

\section{Paradigma Baru}

Revolusi Bumi adalah gerak Bumi pada orbitnya mengelilingi Matahari. Bidang orbit Bumi mengelilingi Matahari disebut ekliptika. Selama mengitari Matahari, poros Bumi selalu miring 23,50 terhadap garis yang tegak lurus ekliptika (lihat gambar 2.). Orbit planet-planet lain tidak sebidang dengan ekliptika. Sudut antara bidang orbit planet lain dengan ekliptika disebut inklinasi.

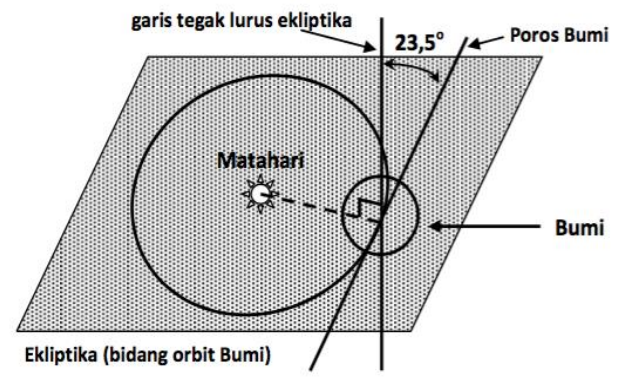

Gambar 2. Poros Bumi selalu miring membentuk sudut $23,5^{\circ}$ terhadap garis yang tegak lurus ekliptika

Bumi berevolusi dalam arah negatif (berlawanan arah jarum jam), artinya jika kita berada dalam pesawat antariksa tepat di atas kutub utara maka kita akan melihat Bumi mengitari Matahari dalam arah yang berlawanan arah jarum jam.

Terdapat dua peristiwa yang dapat membuktikan gerak revolusi Bumi ini:

a. Terjadinya Paralaks Bintang. Paralaks bintang adalah pergeseran kedudukan bintang yang dekat ke Bumi terhadap latar belakang bintang-bintang yang lebih jauh yang disebebkan oleh pengamat di Bumi telah mengubah kedudukannya. Sewaktu pengamat di $P_{A}$, pengamat melihat bintang dekat ke arah $A$. Enam bulan kemudian ketika pengamat di $P_{C}$, pengamat melihat bintang dekat ke arah C (lihat gambar 3.). Jelaslah paralaks bintang membuktikan bahwa Bumi berevolusi mengitari Matahari. 


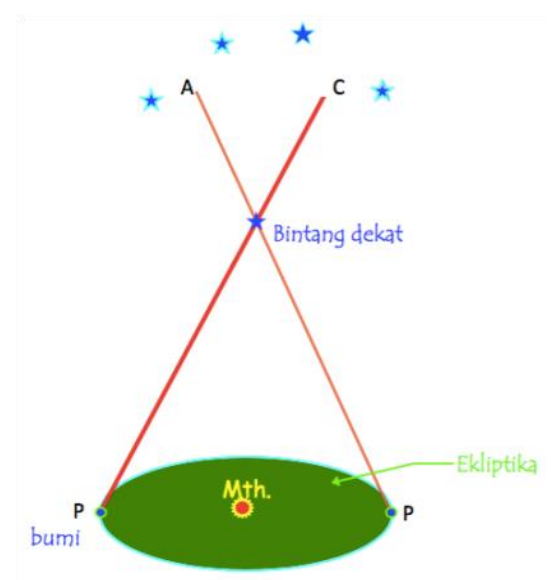

Gambar 3. Paralaks Bintang

b. Terjadinya aberasi cahaya bintang. Aberasi cahaya bintang didefinisikan sebagai perpindahan yang tampak dalam arah cahaya datang dari sebuah bintang akibat gerak revolusi Bumi. Peristiwa aberasi cahaya bintang dapat dianalogikan dengan aberasi tetes-tetes hujan yang menimpa kaca depan mobil. Ketika mobil diam, pengamat dalam mobil melihat tetesan hujan jatuh tegak lurus mengenai kaca, akan tetapi ketika mobil bergerak, tetesan hujan tampak jatuh miring oleh pengamat dalam mobil. Jika aberasi tetes-tetes hujan disebabkan oleh pengamat yang berada dalam mobil yang bergerak, maka aberasi cahaya bintang tentu disebabkan oleh gerakan revolusi Bumi.

Gerak revolusi Bumi ini pun mengakibatkan beberapa peristiwa yang dapat dirasakan oleh para penghuni planet ini, diantaranya adalah:

a. Gerak semu tahunan matahari pada ekliptika. Gerak semu tahuan Matahari adalah gerakan semu Matahari dari khatulistiwa bolak-balik antara $23,5^{\circ}$ lintang utara dan lintang selatan setiap tahun (lihat gambar 4.). Karena Matahari selalu berbalik arah setelah sampai lintang $23,5^{\circ}$ disebut garis balik. Garis $23,5^{\circ} \mathrm{LU}$ disebut garis balik utara (GBU) dan garis $23,5^{\circ} \mathrm{LS}$ disebut garis balik selatan (GBS). Garis lintang adalah garis yang sejajar dengan garis khatulistiwa.

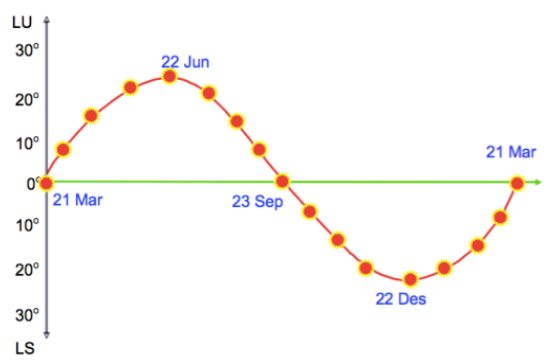

Gambar 4. Bagan gerak semu tahunan Matahari pada ekliptika

b. Perubahan lamanya siang dan malam. Pada tanggal 21 Maret dan 23 September setiap tahunnya, semua tempat di Bumi (kecuali kutub) mengalami siang dan malam hari sama panjang, yaitu 12 jam. Ini karena semua tempat mendapat sinar Matahari selama 12 jam dan tidak mendapatkannya 12 jam. Tanggal 21 Juni ketika Matahari ada pada kedudukan paling utara, yakni 23,5 LU (GBU), belahan Bumi utara mengalami siang lebih panjang daripada malam. Sebaliknya di belahan Bumi selatan, lamanya siang akan lebih pendek daripada malam. Daerah dalam lingkaran kutub utara mendapat sinar Matahari selama 24 jam, sehingga siang akan terjadi secara terus menerus pada 
waktu itu. Sebaliknya di daerah lingkaran kutub selatan tidak mendapat sinar matahari selama 24 jam, sehingga malam terjadi secara terus menerus pada waktu itu.

c. Pergantian musim. Revolusi Bumi dan kemiringan poros Bumi terhadap ekliptika mengakibatkan terjadinya pergantian musim sepanjang tahun di daerah iklim sedang (gambar 5). Dalam revolusi Bumi dari 21 Maret sampai dengan 21 Juni, kutub utara makin condong ke arah Matahari, sebaliknya kutub selatan makin menjauh dari Matahari. Ini menyebabkan belahan Bumi utara mengalami musim semi dan belahan Bumi selatan mengalami musim gugur. Pada tanggal 21 Juni, Matahari berada di GBU dan kutub utara menghadap ke Matahari. Belahan Bumi utara mendapat pemanasan lebih besar dari belahan Bumi selatan, sehingga di belahan Bumi utara mengalami puncak musim panas dan sebaliknya di belahan Bumi selatan akan mengalami musim dingin. Sedangkan pada tanggal 23 September sampai dengan 22 Desember, kutub utara menjauhi Matahari dan sebaliknya belahan Bumi selatan mendekati Matahari. Dalam periode ini belahan Bumi Utara akan mengalami musim dingin (winter) dan belahan Bumi selatan akan mengamai musim panas (summer).

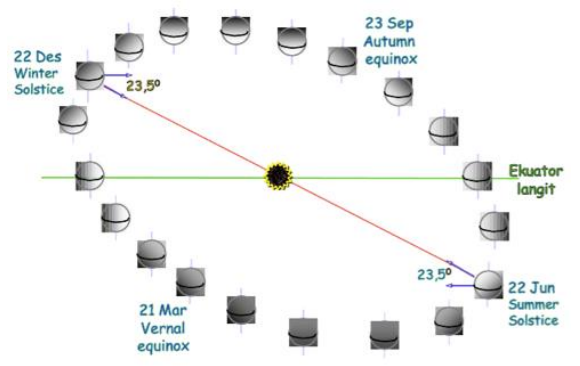

Gambar 5. Belahan Bumi secara bergantian condong ke arah Matahari atau menjauhi Matahari.

d. Terlihatnya rasi bintang yang berbeda dari bulan ke bulan. Gerak revolusi Bumi juga mengakibatkan rasi bintang yang berbeda dari bulan ke bulan. Rasi bintang adalah kumpulan beberapa bintang yang membentuk pola tertentu (Wijaya: 2010).

\section{Pandangan IImuan: Bumi Mengitari Matahari}

Beberapa ilmuan mengungkapkan beberapa pemikiran mereka terkait tentang revolusi bumi mengitari matahari. Pengetahuan mereka di ungkapkan melalui gejala-gejala alam yang terjadi. Ilmuan yang pertama mencetuskan bahwa matahari merupakan pusat tata surya adalah Nicolaus Copernicus teori yang cukup terkenal yang di gagasnya adalah teori Heliosentris. Copernicus menulis buku yang berjudul De Revolutionibus Orbium Coelestium, yang dengan kemudian meruntuhkan teori Geosentris yang telah mapan dan sebagai rujukan berabad-abad (Hambali, 2013).

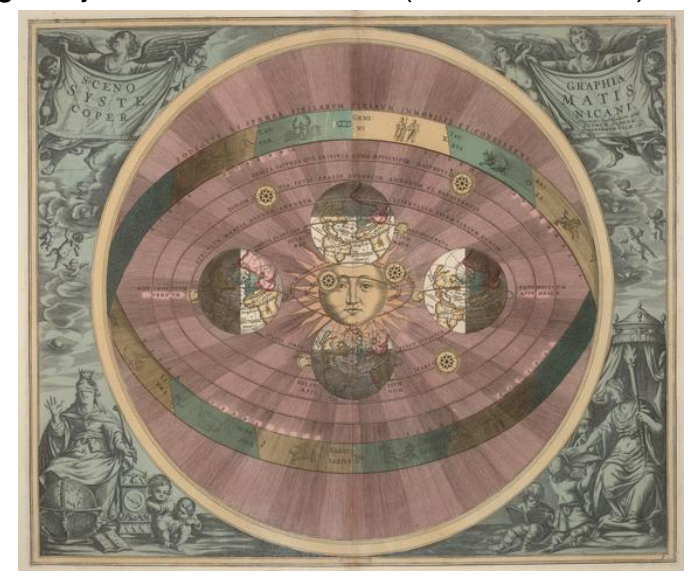

Gambar 6. matahari merupakan pusat tata surya yang dicetuskan oleh Nicolaus Copernicus 
Selain Copernicus, ada beberapa ilmuan yang membuktikan melalui eksperimennya. Berikut ini pembuktian para ilmuan yang terkaji:

a. Bukti pertama, adalah yang ditemukan oleh James Bradley (1725) yang menemukan adanya aberasi bintang.

llustrasi penjelasannya seperti bayangkan kita sedang berdiri ditengah-tengah hujan, dan air hujan jatuh tepat vertikal/tegak lurus kepala kita. Kalau kita menggunakan payung, maka muka \& belakang kepala kita tidak akan terciprat air bukan? Kemudian kita mulai berjalan ke depan, perlahan-lahan \& semakin cepat berjalan, maka seolah-olah air hujan yang tadi jatuh tadi, malah membelok dan menciprati muka kita. Untuk menghindarinya maka kita cenderung mencondongkan payung ke muka. Sebetulnya air hujan itu tetap jatuh tegak lurus, tetapi karena kita bergerak relatif ke depan, maka efek yang terjadi adalah seolah-olah membelok dan menciprat ke muka kita.

Demikian juga dengan fenomena aberasi bintang, sebetulnya posisi bintang selalu tetap pada suatu titik di langit, tetapi dari pengamatan astronomi, ditemukan bahwa posisi bintang mengalami pergeseran dari titik awalnya, pergeserannya tidak terlalu besar, tetapi cukup untuk menunjukkan bahwa memang sebenarnya bumi yang bergerak. Sedangkan penjelasan ilmiahnya di tunjukkan melalui gambar 7 .

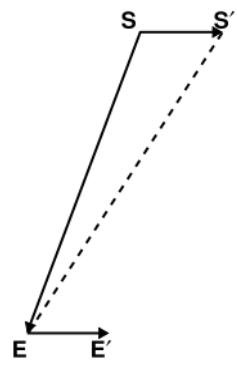

Gambar 7. Analogi pembuktian aberasi bintang.

Aberasi terjadi jika pengamat adalah orang yang berdiri di tengah hujan, dan arah cahaya bintang adalah arah jatuhnya air hujan. Kemudian pengamat bergerak tegak ke muka, tegak lurus arah jatuhnya hujan. S menyatakan posisi bintang, E posisi pengamat di Bumi. Arah sebenarnya bintang relatif terhadap pengamat adalah ES, jaraknya tergantung pada laju cahaya. Kemudian Bumi bergerak pada arah EE' dengan arah garis merepresentasikan lajunya. Ternyata pengamatan menunjukkan bahwa bintang berada pada garis ES' alih-alih ES, dengan SS' paralel \& sama dengan EE'. Maka posisi tampak bintang bergeser dari posisi sebenarnya dengan sudut yang dibentuk antara SES'. Jika memang Bumi tidak bergerak, maka untuk setiap waktu, sudut SES' adalah 0, tetapi ternyata sudut SES' tidak nol. Ini adalah bukti yang pertama yang menyatakan bahwa memang Bumi bergerak.

b. Bukti kedua adalah paralaks bintang.

Bukti ini diukur pertama kali oleh Bessel (1838). Paralaks bisa terjadi jika posisi suatu bintang yang jauh, seolah-olah tampak 'bergerak' terhadap suatu bintang yang lebih dekat. (Gambar 8). Fenomena ini hanya bisa terjadi, karena adanya perubahan posisi dari Bintang akibat pergerakan Bumi terhadap Matahari. Perubahan posisi ini membentuk sudut $p$, jika kita ambil posisi ujung-ujung saat Bumi mengitari Matahari. Sudut paralaks dinyatakan dengan (p), merupakan setengah pergeseran paralaktik bilamana bintang diamati dari dua posisi paling ekstrim. 


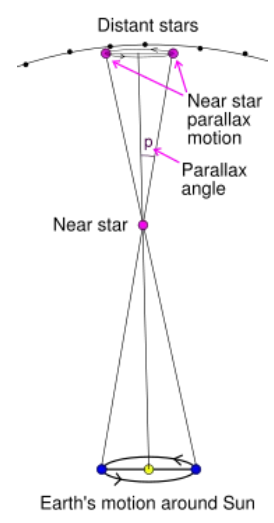

Gambar 8. paralaks bintang

Bagaimana kita bisa menjelaskan fenomena ini? Ini hanya bisa dijelaskan jika Bumi mengitari Matahari, dan bukan kebalikannya.

c. Bukti ketiga adalah adanya efek Doppler.

Sebagaimana yang telah diperkenalkan oleh Newton, bahwa ternyata cahaya bisa dipecah menjadi komponen mejikuhibiniu, maka pengetahuan tentang cahaya bintang menjadi sumber informasi yang sahih tentang bagaimana sidik jari bintang. Ternyata pengamatan-pengamatan astronomi menunjukkan bahwa banyak perilaku bintang menunjukkan banyak obyek-obyek langit mempunyai sidik jari yang tidak berada pada tempatnya. Penjelasannya diberikan oleh Doppler (1842), bahwa jika suatu sumber informasi 'bergerak' (informasi ini bisa suara, atau sumber optis), maka terjadi 'perubahan' informasi. Ini bisa terjadi karena pergerakannya adalah pergerakan relatif, apakah karena pengamatnya yang bergerak, tau sumbernya yang bergerak.

Demikian pada sumber cahaya, jika sumber cahaya mendekat maka gelombang cahaya yang teramati menjadi lebih biru, kebalikannya akan menjadi lebih merah. Ketika Bumi bergerak mendekati bintang, maka bintang menjadi lebih biru, dan ketika menjauhi menjadi lebih merah.

Di suatu ketika, pengamatan bintang menunjukkan adanya pergeseran merah, tetapi di saat yang lain, bintang tersebut mengalami pergeseran Biru. Ini menjadi bukti, bahwa ternyata Bumi bergerak (bolak-balik - karena mengitari Matahari), mempunyai kecepatan, relatif terhadap bintang dan tidak diam saja.

Dengan demikian ada tiga bukti yang mendukung bahwa memang Bumi bergerak mengitari matahari, dari aberasi (perubahan kecil pada posisi bintang karena laju Bumi), paralaks (perubahan posisi bintang karena perubahan posisi Bumi) dan efek Doppler (perubahan warna bintang karena laju Bumi). (Sungging, 2007).

\section{Bantahan Ilmuan: Bumi Mengitari Matahari}

Menurut pandangan bangsa babilonia, mereka percaya bahwa bumi merupakan pusat alam semesta dan mereka beranggapan bumi sebagai suatu gunung yang berongga di bawahnya ditopang oleh suatu Samudra. Angkasa melengkung di atas bumi berdiri tegak di antara perairan bawah dan perairan atas Samudra, siang kadang-kadang turun ke bumi berupa hujan.

Sewaktu ilmu pengetahuan modern mulai berkembang setelah Eropa kembali ke zaman kebangkitan pada abad ke 17, pandangan orang mengenai asal usul kehidupan dibentuk oleh ajaran yang tercantum dalam perjanjian lama pada kitab genesis. Dalam kitab ini memuat ajaran tentang bumi yang mirip dengan pandangan orang Babilonia. Bedanya bahwa angkasa di langit ada suatu tempat yang disebut surga yaitu tempat Tuhan Yang Maha esa bertahta, sedangkan di bawah bumi terdapat suatu tempat yang disebut neraka seperti gambaran 9 . 


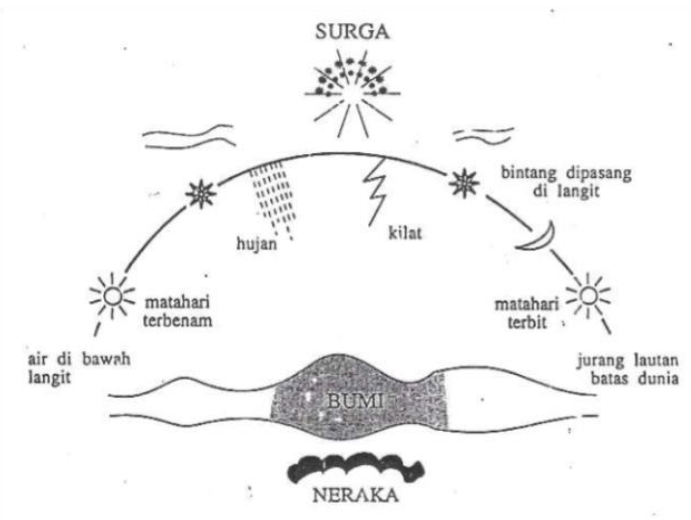

Gambar 9. Pandangan ajaran kitab genesis.

Sebagian besar bangsa Yunani kuno percaya bahwa bumi adalah pusat alam raya. Pada sekitar akun 140 Masehi muncul teori Ptolemaeus tentang sistem tata surya di dalam semesta yang didasari oleh konsep geosentrisme (Lusiana).

Teori yang cukup terkenal yang mengemukakan bahwa bumi adalah sebagai pusat tata surya adalah teori Geosentis. Geosentrisme atau disebut Teori Geosentrik, adalah istilah astronomi yang menggambarkan alam semesta dengan bumi sebagai pusatnya dan pusat pergerakan semua bendabenda langit. Model ini menjadi sistem kosmologi predominan pada budaya kuno misalnya Yunani kuno, yang meliputi sistem-sistem terkenal yang dikemukakan oleh Aristoteles dan Claudius Ptolemaeus. (Lawson, 2004)

Dua pengamatan umum mendukung pandangan bahwa Bumi adalah pusat dari alam semesta. Pengamatan pertama adalah bintang-bintang, matahari dan planet-planet nampak berputar mengitari bumi setiap hari, membuat bumi adalah pusat sistem ini. Lebih lanjut, setiap bintang berada pada suatu bulatan stelar atau selestial ("stellar sphere" atau "celestial sphere"), di mana bumi adalah pusatnya, yang berkeliling setiap hari, di seputar garis yang menghubungkan kutub utara dan selatan sebagai aksisnya. Bintang-bintang yang terdekat dengan khatulistiwa nampak naik dan turun, tetapi setiap bintang kembali ke titik terbitnya setiap hari. Observasi umum kedua yang mendukung model geosentrik adalah bumi nampaknya tidak bergerak dari sudut pandang pengamat yang berada di bumi, bahwa bumi itu solid, stabil dan tetap di tempat. Dengan kata lain, benar-benar dalam posisi diam.

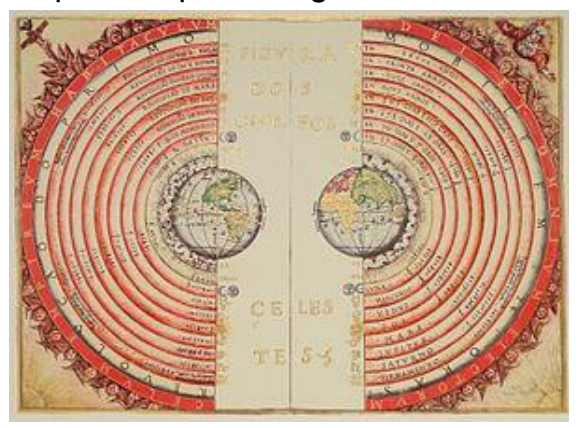

Gambar 10. Pandangan teori geosentris, bumi sebagai pusat tatasurya.

Adapun ilmuan yang sependapat dengan teori geosentris diantaranya adalah:

a. Pandangan Pertama, oleh Sheikh Bandar al-Khaibari.

Seorang dosen di salah satu Universitas di Uni Emirat Arab menjadi bahan tertawaan sejumlah siswa dan pengguna internet karena mengatakan "Bumi tidak bergerak pada porosnya dan Mataharilah yang mengelilingi Bumi" Dilansir Daily Mail (Surat kabar dari UK), Sheikh Bandar Al Khaibari mengklaim bumi itu statis tidak bergerak dan matahari mengelilingi bumi setelah salah seorang mahasiswanya bertanya mengenai rotasi bumi. 
Setelah mengatakan kalau bumi itu tidak berotasi dan mataharilah yang mengelilingi bumi, sang dosen tampaknya sadar kalau mahasiswanya kebingungan dan tak sependapat dengan dirinya sehingga Sheikh al-Khaibari berusaha untuk mempertahankan pendapatnya dan mengutip sejumlah pendapat ulama dan pernyataan al-Quran dan Hadits. Mungkin, karena argumennya sangat sulit dimengerti ia membuat sebuah ilustrasi sebuah pesawat tidak akan bisa terbang kalau bumi itu berputar. "Dimana kita sekarang? kita tidak kemana - mana kan, coba kalau naik pesawat misalkan ke China, kita bisa sampai ke tujuan, itu karena bumi tidak bergerak," kata Sheikh Bandar al-Khaibari.

Dalam sebuah laporan berita Al Arabiya Saudi cleric Sheikh Bandar al-Khaibari pernah mengatakan NASA itu hanyalah rekayasa Hollywood, tidak ada manusia yang pernah ke Bulan. Seorang pengguna menunjukkan bahwa cuplikan tersebut pertama kali muncul pada 15 Februari saat ulang tahun ke 451 kelahiran Galileo Galilei. Galileo terkenal dua kali dituduh bi'dah oleh Gereja Katolik setelah secara terbuka mendukung teori Copernican bahwa Bumi dan planet lain berputar mengelilingi matahari.

b. Pandangan Kedua, oleh Ahmad Sabiq bin Abdul Lathif Abu Yusuf dalam bukunya yang berjudul "Bantahan Terhadap Teori Bumi Mengelilingi Matahari".

Selain menjelaskan dalam pemahaman quran dan hadits, Ahmad Sabiq juga membuat sebuah realita yang mengagumkan dan membuktikan bahwa matahari mengitari bumi (Sabiq: 2008). Berikut ini realita yang di jelaskan oleh Ahmad Sabiq dalam bukunya:

- Siapapun yang menyaksikan keagungan penciptaan langit dan bumi akan melihat dengan mata kepalanya sendiri bahwa matahari setiap pagi terbit dari ufuk timur lalu bergerak ke pertengahan lalu terbenam di barat. Itulah kejadian alam yang tidak ada seorang pun yang mengingkarinya. Itu sebagai bukti bahwa matahari yang bergerak. Namun kita diajarkan bahwa pergerakan matahari ke arah barat karena gerakan rotasi bumi. Lalu kalau ditanya kenapa yang terlihat bergerak itu matahari? Maka dijawab bahwa itu sama dengan seseorang yang naik mobil yang cepat, maka seolah-olah dia merasakan bahwa yang bergerak adalah pohon dan bangunan disekitarnya dan orang itu merasa kayaknya diam dalam mobil. Namun kalau difikirkan lebih lanjut bahwa secepat apapun mobil yang dinaiki seseorang, maka orang tersebut akan tetap merasakan bahwa dia bergerak.

- Lihatlah awan yang ada di atas kita, dia tidak berada di bumi ataupun dilangit tetapi berada di antara keduanya. Lalu, mengapa awan itu terkadang bergerak ke barat atau ke timur, atau ke utara, atau ke selatan? Seandainya bumi berotasi maka mestinya awan itu bergerak sama dengan arah rotasi bumi. Tapi ternyata?

- Jika kita naik pesawat misal dari Indonesia ke Saudi Arabia, lalu pesawat itu diarahkan ke atas sehingga keluar dari gaya gravitasi bumi, maka apakah pesawat itu butuh bergerak ke barat ataukah cukup diam di tempat menunggu bumi berotasi atau bagaimana?

Pandangan Ahmad Sabiq ini juga di dapatkan dari berbagai ulama-ulama islam yang telah masyhur.

\section{PENUTUP}

Sampai saat ini teori dari Heliosentris yang mengemukakan bahwa matahari sebagai pusatnya sudah menjadi darah daging oleh banyak ilmuan. Bahkan seluruh lembaga kependidikan telah bersepakat bahwa benar matahari adalah pusat dari tata surya, dan seluruh planet yang berada dalam galaksi bima sakti berevolusi terhadap matahari. Akan tetapi teori ini tidak selamanya bersifat absolut, ada kemungkinan teori ini akan berubah dan kembali para ilmuan mempercayai teori dari geosentris.

Perlu di ketahui, bahwa sampai saat ini belum ada alat manusia yang mampu menembus langit, yang kita ketahui adalah bahwa pernah ada pesawat AS pernah mendarat jauh di bulan, meskipun banyak ilmuan tidak percaya terhadap kenyataan ini. Sehingga dapat di simpulkan lebih dalam, bahwa belum ada pembuktian empiris yang benar-benar menjelaskan peredaran alam semesta, yang para ilmuan lakukan dalam pembuktiannya adalah hanya sampai pada gejala-gejala alam. 
Pembuktian empiris tentang penetapan evolusi gejala alam akan sulit untuk di buktikan, ini karena sebenarnya disebabkan kita tidak mampu menentukan koordinat sesungguhnya di alam semesta, misalnya ketika kita membayangkan struktur bumi yang berbentuk bulat, kita akan kesulitan menentukan di mana posisi atas atau bawah dari bumi. Contoh lain, ketika kita ingin menetapkan mana yang benar "Bumi yang mengelilingi matahari atau Matahari yang mengelilingi Bumi?", kita akan berbeda menyimpulkan antara seorang pengamat yang berada di bumi dan pengamat yang ada di matahari. Barangkali kita dapat menambah kesimpulan tentang teori ini, bahwa sebenarnya kebenaran itu adalah relatif, jika di perbolehkan penulis mengatakan bahwa kebenaran yang absolut adalah kebenaran dari Tuhan.

Penutup berisi simpulan dan saran. Simpulan memuat jawaban atas pertanyaan penelitian. Saran-saran mengacu pada hasil penelitian dan berupa tindakan praktis, sebutkan untuk siapa dan untuk apa saran ditujukan. Bagian penutup ditulis dalam bentuk essay, bukan dalam bentuk numerikal.

\section{UCAPAN TERIMAKASIH}

Ucapan terimakasih ditujukan kepada institusi resmi atau perorangan sebagai penyandang dana, atau yang telah memberikan kontribusi lain dalam penelitian. Ucapan terimakasih dilengkapi dengan nomor surat kontrak penelitian.

\section{DAFTAR PUSTAKA}

Anonim. Bumi Mengelilingi Matahari?. Di akses pada 19 April 2017 di:

http://repo.unnes.ac.id/dokumen/astrodb/pdf/Benarkah\%20Bumi\%20Mengelilingi\%20Matahari. pdf

Cuk, Matija. (2015). Is there a proof that Earth moves?. Di akses pada 20 April 2017 di:

http://curious.astro.cornell.edu/physics/41-our-solar-system/the-earth/orbit/88-is-there-a-proofthat-earth-moves-intermediate

Gantira, Uung. (2015). Bukti Matahari Mengelilingi Bumi. Diakses tanggal 19 April 2017 di: http://www.kompasiana.com/uung_gantira/yang-benar-itu-bumi-memutari-matahari-ataumatahari-memutari-bumi_5510c924813311583bbc6c9a

Hall, John. (2015). Saudi cleric becomes online laughing stock after telling student the sun rotates around the Earth as otherwise planes would not be able to fly. Di akses pada 19 April 2017 di: http://www.dailymail.co.uk/news/article-2957414/Saudi-cleric-online-laughing-stock-tellingstudent-sun-rotates-Earth-planes-not-able-fly.html

Hambali, Slamet. (2013). Astronomi Islam Dan Teori Heliocentris Nicolaus Copernicus. AlAhkam, 23(2), 225-236.

Kristanti, Elin Yunita. (2014). 1 dari 3 Orang AS yakin Matahari Bergerak Mengelilingi Bumi. Di akses pada 19 April 2017 di:

http://global.liputan6.com/read/829187/1-dari-4-orang-as-yakin-matahari-bergerak-mengelilingibumi

Lusiana, Mariani Safitri, Elly Susanti. Perkembangan Pemikiran Tentang Pembentukan Alam Raya. Di akses pada 19 April 2017 di:

http://www.geocities.ws/m_win_afgani/arsip/11_PEMBENTUKAN_ALAM_SEMESTA 
32 | Titian IImu: Jurnal IImiah Multi Sciences, Vol. IX No. 1, 2017

Sabiq, Ahmad. (2008). MATAHARI MENGELILINGI BUMI Sebuah Kepastian Al-Quran dan As-Sunnah Serta Bantahan Terhadap Teori Bumi Mengelilingi Matahari. Penerbit: Pustaka Al-Furqon: Jakarta.

Sungging, Emanuel. (2007). Bukti Bumi Mengelilingi Matahari. Di akses pada 19 April 2017 di: http://langitselatan.com/2007/04/21/bagaimana-membuktikan-bahwa-bumi-mengelilingimatahari-dan-bukan-sebaliknya/

Wijaya, Agus Fany Chandra. (2010). Gerak Bumi dan Bulan. Digital Learning Lesson Study Jayapura 